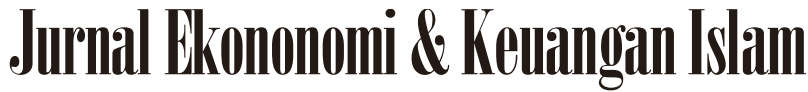

\author{
Available at http://journal.uii.ac.id/index.php/jeki
}

\section{Faktor-faktor yang mempengaruhi deposito mudharabah pada bank syariah di Indonesia}

\author{
Nila Juniarty, Mustika Noor Mifrahi, dan Achmad Tohirin \\ Fakultas Ekonomi, Universitas Islam Indonesia, Yogyakarta \\ e-mail: nilajuniarty12@gmail.com
}

\section{Keywords: \\ mudharabah deposits, proit- sharing rate, inflation, interest rate, promotion. \\ DOI: \\ 10.20885/JEKI.vol3.iss1.art5}

\begin{abstract}
Mudharabah Deposit is one of Islamic banking products, which is the biggest contributor to sharia banking compared to other collecting products. In addition, according to Bank Indonesia's report, the number of Islamic banking deposits each year has increased significantly. Therefore, in this study, the authors want to know the factors that are expected to affect the number of mudharabah deposits. There are 6 factors that are expected to affect the number of deposits, namely the profit-sharing rate, the interest rate, the promotion rate, the inflation rate, the FDR, and the number of offices. The authors use a weighted average in terms of rate of profit sharing and interest rate and data processing using multiple linear regression. The results of these regression calculations, simultaneously show positive and significant results for all variables. This value resulted from the four regression has a value of sig-F 0.000 is smaller than 10\% significance. Partially, profit sharing, promotion cost and number of offices show significant and positive effect on total mudharabah deposit, while interest rate, inflation and FDR show no effect on mudharabah deposit amount.
\end{abstract}

\begin{abstract}
Abstrak
Deposito Mudharabah di bank syariah memiliki karaktersitik yang berbeda dengan produk deposito di perbankan konvensional. Akad mudharabah yag digunkana berimplikasi pada pembagian bagi hasil yang tidak menentu. Akan tetapi, dilihat dari laporan Bank Indonesia, jumlah deposito perbankan syariah setiap tahunnya mengalami kenaikan yang cukup signifikan. Tujuan dari penelitian ini penulis ingin mengetahui faktor apa saja yang dapat mempengaruhi jumlah deposito mudharabah. Variabel yang diuji yaitu tingkat bagi hasil, tingkat suku bunga, baiya promosi, inflasi, FDR, dan jumlah kantor. Penulis menggunakan rata-rata tertimbang dalam menghitung tingkat bagi hasil dan stingkat suku bunga dan mengolah data menggunakan regresi linier berganda. Hasil pengujian regresi linier secara simultan menunjukan hasil yang positif dan signifikan semuanya. Hal ini dibuktikan dari keempat regresi tersebut mempunyai nilai sig-F 0,000 yang lebih kecil dari signifikansi 10\%. Secara parsial, tingkat bagi hasil, biaya promosi dan jumlah kantor menunjukan hasil signifikan dan berpengaruh positif terhadap jumlah deposito mudharabah, sedangkan tingkat suku bunga, inflasi dan FDR menunjukan tidak berpengaruh terhadap jumlah deposito mudharabah.
\end{abstract}

\section{Pendahuluan}

Bank syariah sebagai pemegang asset terbesar dalam industri keuangan menunjukkan peningkatan yang signifikan dari tahun ke tahun. Statistik perbankan syariah menunjukkan peningkatan penghimpunan Dana Pihak Ketiga hingga tahun 2014 melampaui pertumbuhan DPK pada perbankan konvensional. Peningkatan DPK tertinggi terjadi pada deposito mudharabah yang diiukuti dengan tabungan wadi'ah dan mudharabah (Wulandari \& Aisjah, 2014).

Hadirnya perbankan syariah memberikan angin segar bagi muslim di Indonesia. Didukung dengan adanya UU No 21 tahun 2008 tentang Perbankan Syariah, bank syariah mampu memberikan produk-produk sesuai dengan permintaan konsumen. Produk dengan sistem berbasis syariah yang ditawarkan terbukti mampu bersaing dengan pebankan konvensional.

Produk penghimpunan dana pada bank syariah yang sangat berbeda dengan produk bank konvesional adalah deposito mudharabah. Deposito mudharabah pada bank syariah dijalankan beradasarkan syariat Islam. Landasan hukum deposito mudharabah dikeluarkan oleh Dewan Syariah Nasional (DSN) mengenai deposito syariah. Fatwa DSN-MUI No: 03/DSN-MUI/IV/2000 disebutkan bahwa deposito yang tidak dibenarkan secara syariah yaitu deposito yang berdasarkan perhitungan bunga, karena bunga merupakan riba. Deposito yang dibenarkan, yaitu deposito yang berdasarkan prinsip mudharabah yang menggunakan sistem bagi hasil (Karim, 2004). 
Bagi hasil (profit sharing) pada produk penghimpunan dana terjadi kerja sama anatara mudharib dan shahibul maal. Bank bertindak sebagai mudharib dengan nasabah sebagai shahibul maal terjadi kesepakatan diamana simpanan yang ditabung di bank syariah akan dikelola oleh bank syariah, selanjutnya hasil atau keuntungan dari pengelolaan dana tersebut dibagi menurut nisbah yang disepakati bersama. Tingkat bagi hasil yang tinggi akan menarik nasabah lebih banyak. Berbeda dengan bank konvensional dimana keuntungan didasarkan pada bunga yang sifatnya pasti dan tetap dari satu periode ke peeriode selanjutya.

Pada bank syariah sistem bagi hasil dapat bersaing secara kompetitif terhadap suku bunga di bank konvensional. Saat suku bunga bank konvensioanal meningkat maka bagi hasil pada bank syariah jadi kurang kompetitif, akibatnya akan terjadi pengurangan dana pihak ketiga di perbankan syariah. Dan sebaliknya jika bank syariah menawarkan bagi hasil lebih tinggi dari suku bunga pada bank konvensional maka akan terjadi peningkatan dana pihak ketiga di bank syariah. Hal ini dibuktikan dengan adanya penelitian yang telah dilakukan oleh Wulansari (2015) yang menyatakan bahwa bagi hasil dan suku bunga mempunyai pengaruh negatif dan signifikan terhadap jumlah deposito mudharabah. Begitu juga pada penelitian yang dilakukan oleh Nelwani (2013).

Sebagaimana perkembangan bank syariah di Indonesia, Malaysia yang telah lebih dulu mengenalkan perbankan syariah juga menghadapi hal kompleks dalam pengembangan deposito mudharabah. Salah satu penelitian yang dilakukan oleh Haron dan Nursofiza (2008) menunjukkan perbedaan hasil dimana tingkat imbal hasil yang ditawarkan bank syariah berpengaruh terhadap jumlah deposito pada bank syariah.

Pada penelitian lainnya Inflasi, biaya promosi, FDR, dan jumlah kantor merupakan variabel independen yang mempengaruhi tingkat deposito mudharabah. Menurut Mutaqqiena (2013) Inflasi secara (parsial) berpengaruh negatif dan signifikan terhadap deposito mudharabah. Pada penelitian yang dilakukan oleh Nelwani (2013) biaya promosi berpengaruh positif dan signfikan terhadap simpanan mudharabah, yang artinya ketika suatu perusahaan melakukan promosi pada produknya dengan baik maka akan menarik masyarakat untuk menaruh dananya pada perusahaan tersebut.

Nelwani (2013) menemukan tingkat bagi hasil, biaya promosi, suku bunga dan inflasi berpengaruh signifikan terhadap deposito mudharabah. Namun secara (parsial) terhadap deposito mudharabah, inflasi dan suku bunga berpengaruh negatif. Sedangkan tingkat bagi hasil dan biaya promosi memiliki pengaruh positif terhadap deposito mudharabah.

Selanjutnya penelitian yang dilakukan Anisah (2013) pada deposito mudharabah menunjukan pertumbuhan deposito mudharabah 1 bulan sebagai variabel terikat dipengaruhi secara signifikan oleh tingkat bagi hasil dan tingkat suku bunga. Sedangkan untuk variabel bebas inflasi tidak mempunyai pengaruh signifikan terhadap variabel terikat deposito mudharabah. Pengaruh positif pada tingkat bagi hasil menunjukan bahwa nasabah bank syariah masih berorientasi pada profit. Apabila tingkat bagi hasil yang diberikan oleh bank syariah lebih tinggi, maka nasabah akan lebih cendrung menempatkan dananya dalam deposito mudharabah begitu pula sebaliknya.

Mutaqqiena (2013) pada variabel Inflasi dan tingkat suku bunga secara berasamaan maupun masingmasing (parsial) berpengaruh signifikan terhadap DPK Perbankan syariah. Diamana inflasi berpengaruh negatif signifkan dan suku bunga berpengaruh positif signifikan terhadap DPK perbankan syariah. Hasil yang signifikan menunjukan bahwa DPK perbankan syariah sangat dipengaruhi oleh perubahan-perubahan yang terjadi pada indikator-indikator makro ekonomi.

Rudiansyah \& Wuryani (2014) melakukan pengujian antara inflasi dan BI rate terhadap simpanan mudharabah. Pada variabel independen inflasi dan BI rate secara bersamaan memiliki perpengaruh terhadap simpanan mudharabah, sedangkan secara parsial inflasi berpengaruh signifikan terhadap tabungan mudharabah, sedangkan BI rate tidak berpengaruh signifikan terhadap tabungan mudharabah.

Berdasarkan latar belakang yang telah dijabarkan, penelitian ini akan menganalisis mengenai faktorfaktor yang mempengaruhi deposito mudharabah. Varibel yang digunakan adalah tingkat bagi hasil, tingkat suku bunga, promosi, inflasi, FDR, dan jumlah kantor sebagai variabel independen. Adapun periode tahun yang diambil yaitu dari tahun $2011-2015$.

\section{Metode Analisis}

Penelitian ini menggunakan pengujian regresi berganda. Metode regresi dinilai mampu memggambarkan model regresi yang diajukan. Adapun model regresi berganda pada penelitian ini adalah

$$
Y=\beta_{0}+\beta_{1} X_{1}+\beta_{2} X_{2}+\beta_{3} X_{3}+\beta_{4} X_{4}+\beta_{5} X_{5}+\beta_{6} X_{6}+e_{i}
$$

Dimana Y adalah deposito Mudharabah, X1 adalah tingkat imbal hasil, X2 adalah tingkat suku bunga, X3 adalah biaya promosi, X4 adalah inflasi, X5 adalah FDR, X6 adalah jumlah kantor. Sedangkan $\beta 0$ adalah konstanta dan $\beta 1, \beta 2, \beta 3, \beta 4, \beta 5, \beta 6$ merupakan koefisien regresi. 
Implikais dari akad Mudharabah adalah adanya pembagian hasil usaha dengan porsi nisbah yang telah disepakati di awal transaksi. Pemilik dana (shahibul maal) dalam hal ini nasabah memberikan dana kepada bank atau dana (mudharib) untuk melakukan usah produktif. (Ascarya, 2006).

Idealnya, dengan penggunaan profit sharing, tingkat imbal hasil tabungan mudharabah yang diberikan oleh bank untuk deposito nasabah lebih tinggi dibandingkan dengan tabungan mudharabah (Ismail, 2010). Data mengenai jumlah deposito diperoleh dari laporan keuangan tahunan bank. data deposito mudharabah yang digunakan baik deposito 1 bulan, 3 bulan, 6 bulan maupun satu tahu. Sebagaimana dalam Undang-Undang perbankan Nomor 10 tahun 1998 adalah simpanan yang penarikannya hanya dapat dilakaukan pada waktu tertentu berdasarkan perjanjian nasabah dengan bank.

\section{Bagi Hasil}

Bagi hasil atau profit sharing ditentukan berdasarkan kinerja bank syariah. Perhitungan besarnya porsi masingmasing pihak tidak jauh berbeda dengan penentuan biaya dana dan penentuan tingkat bunga pembiayaan pada bank konvensional. Namun dengan sudut pandang yang berbeda, karena bank konvensional didasarkan pada biaya sedangkan bank Islam di dasarkan pada besar kecilnya pendapatan.

Bagi hasil pada bank Islam dapat diartikan sebagai perolehan aktivitas usaha dengan kontrak investasi dengan jangka waktu tertentu dan tidak dapat ditentukan secara pasti jumlahnya. Banyak atau sedikit jumlah yang diperoleh sangat bergantung pada investasi yang diusahakan oleh bank syariah.

Besarnya porsi bagi hasil antara bank dan nasabah telah ditentukan sebelumnya pada awal transaksi. Nisbah bagi hasil yang disepakati antara kedua belah pihak ditentukan sesuai kesepakatan bersama, dan harus terjadi dengan adanya kerelaan (At-Tarrodhin) oleh masing-masing pihak tanpa ada unsur paksaan (Rivai \& Arifin, 2010).

Data tingkat bagi hasil deposan diperoleh dari data sekuner laporan statistik perbankan syariah. Tingkat bagi hasil yang diterima nasabah secara riil yang diberikan oleh lembaga keuangan kepada nasabah bank syariah.

\section{Suku Bunga}

Dalam teori klasik tingkat suku bunga adalah "harga" yang terjadi di "pasar" dana investasi (loanable funds). Tingkat suku bunga ditentukan oleh permintaan tabungan dan penawaran tabungan. Maskudnya adalah didalam masyarakat yang memperoleh pendapatan melebihi kebutuhan konsumsi yang di perlukan. Secara bersama-sama jumlah seluruh tabungan membentuk supply penawaran akanloanable funds. Selanjutnya para penabung dan para investor yaitu pengusaha yang memerlukan dana untuk operasional atau perluasan usahanya membentuk demand atau permintaan, bertemu di pasar loanable funds, dan dari proses tawar menawar antara mereka yang akhirnya akan dihasilkan tingkat bunga yang disepekati (Boediono,1994).

Secara berkala Bank Indonesia menetapkan suku bunga acuan bagi industri perbankan di Indonesia. Tingkat suku bunga acuan Bank Indonesia dikenal dengan BI rate. BI rate merupakan sikap kebijakan moneter sebagai regulator perbankan yang ada di Indonesia.

\section{Promosi}

Promosi merupakan kegiatan terpenting yang berperan aktif dalam memperkenalkan, memberitahukan dan mengingatkan kembali manfaat suatu produk. Hal ini bertujuan untuk mendorong konsumen membeli produk yang dipromosikan tersebut.

Dalam dunia perbankan, agar produk perbankan laku dijual ke masyarakat atau nasabah, maka masyarakat perlu tahu kehadiran produk tersebut. Cara untuk memberitahukan kepada masyarakat yaitu melalui sarana promosi. Bank harus mempromosikan produk tersebut seluas mungkin ke nasabah. Untuk dapat menarik calon nasabah bank perlu menjelaskan mengenai jenis produk yang ditawarkan serta keunggulan lainnya dalam promosinya (Roziq, 2013). Data mengenai promosi perbankan syariah dilihat berdasarkan total biaya promosi yang menjadi beban perbankan syariah.

\section{Inflasi}

Inflasi pada umumnya diketahui adalah suatu keadaan dimana harga barang secara umum mengalami kenaikan secara terus menerus atau terjadi penurunan nilai uang dalam negeri. Inflasi diartikan sebagai kenaikan pada tingkat harga atas barang dan jasa secara umum dimana barang dan jasa tersebut merupakan kebutuhan pokok masyarakat atau turunnya daya jual mata uang suatu negara. Sama halnya dengan pendapat Boediono dimana inflasi adalah kecenderungan dari harga-harga untuk naik secara umum dan terus menerus. (Boediono,1985).

Pengalaman di berbagai negara yang mengalami inflasi menunjukan bahwa beberapa penyebab inflasi adalah; terlalu banyaknya JUB, upah, krisis energi, paceklik, kekeringan dan defisit anggaran. Analisis ekonomi 
inflasi mempunyai dua jalur yang berbeda-beda yaitu; (i) memusatkan perhatian pada hubungan antara pertumbuhan JUB dengan inflasi serta menelusuri sebab-sebab yang bersifat "ekonomi politik "dari JUB. (ii) mencoba menganalisis inflasi secara "struktural-instutional" berdasarkan konsep sosiologi terhadap manusia (Iswardono, 1979).

\section{Financing to Deposit Ratio (FDR)}

FDR adalah rasio pembiayaan yang diberikan kepada pihak ketiga dalam rupiah dan valuta asing, tidak termasuk pembiayaan kepada bank lain, terhadap dana pihak ketiga yang mencakup giro, tabungan, deposito dalam rupiah dan valuta asing, tidak termasuk antar bank

FDR tersebut menggambarkan tingkat kemampuan bank dalam membayar kembali penarikan dana yang dilakukan deposan dengan mengandalkan pembiayaan yang diberikan sebagai sumber likuiditasnya. Semakin besar pembiayaan yang dsalurkan maka pendapatan yang diperoleh naik, karena pendapatan mengalami kenaikan maka dapat dipastikan laba bank juga akan mengalami kenaikan.

Muhammad (2005), penyaluran pembiayaan adalah pendanaan yang dikeluarkan untuk mendukung investasi yang di rencanakan. Variabel ini diwakili oleh FDR (Financing to Deposit Ratio). FDR merupakan perbandinga antara pembiayaan yang diberikan oleh bank dengan dana pihak ketiga yang berhasil dihimpun.

\section{Jumlah Kantor}

Bank syariah dengan segala keterbatasannya membutuhkan akselerasi yang cepat untuk menarik nasabah. Salah satu yang dapat diupayakan adalah dengan peningkatan fasilitas pelayanan bank syariah. Fasilitas bank syariah yang lengkap akan memberikan kemudahan kepada nasabah dalam berinteraksi. Selain itu bank syariah dengan jangkauan kantor cabang dan kantor cabang pembantu, memungkinkan adanya pelayanan yang lebih baik dalam memberikan service dan kemudahan bagi para nasabah.

Berdasarkan penelitian Bank Indonesia pada tahun 2000 diketahui bahwa kemudahan dan kedekatan lokasi bank syariah dengan pusat kegiatan masyarakat menentukan akses masyarakat terhadap bank syariah. Jumlah kantor dihitung yang dihitung dalam penelitian ini adalah semua kantor pusat hingga kantor cabang yang dimiliki oleh bank syariah.

\section{Hasil dan Pembahasan}

Setelah dilakukan pengujian mengenai variabel yang dapat mempengaruhi deposito pada bank syariah maka diperoleh hasil sebagai berikut:

\begin{tabular}{rrrrr}
\multicolumn{1}{c}{ Variable } & Coefficient & Std. Error & t-Statistic & Prob. \\
\hline \hline C & -62.20891 & 24.2396 & -2.5664 & 0.0135 \\
X1 & 0.6454 & 0.2268 & 2.8459 & 0.0065 \\
X2 & 2.0307 & 2.1322 & 0.9524 & 0.3458 \\
X3 & 0.0140 & 0.0080 & 1.7453 & 0.0875 \\
X4 & -1.2711 & 1.0909 & -1.1651 & 0.2499 \\
X5 & -0.2358 & 0.1458 & -1.6173 & 0.1125 \\
X6 & 93.0921 & 8.7944 & 10.5853 & 0.0000 \\
\hline R-squared & 0.9673 Mean dependent var & & 91.7969 \\
Adjusted R-squared & 0.9632 S.D. dependent var & & 28.4985 \\
S.E. of regression & 5.4668 Akaike info criterion & & 6.3556 \\
Sum squared resid & 1404.650 Schwarz criterion & & 6.6135 \\
Log likelihood & -164.6038 Hannan-Quinn criter. & & 6.4551 \\
F-statistic & 232.2157 Durbin-Watson stat & & 0.5140 \\
Prob(F-statistic) & 0.0000 Wald F-statistic & & 143.4438 \\
Prob(Wald F-statistic) & 0.0000 & \\
\hline
\end{tabular}

Hasil dari estimasi model linier menghasilkan $\mathrm{R}^{2}$ sebesar 0.9673 artinya bahwa $96.73 \%$ variasi variabel dependen (deposito mudharabah) dapat dijelaskan oleh variabel independen (tingkat bagi hasil, tingkat suku bunga, biaya promosi, inflasi, FDR, jumlah kantor), sedangkan sisanya sebesar $3.27 \%$ dijelaskan oleh variabel lain diluar model.

Nilai $\mathrm{F}$ dari pengujian regresi menolak $\mathrm{H}_{0}$ artinya secara bersama-sama variabel independen mampu berpengaruh signifikan terhadap variabel dependen. 
Dapat disimpulkan bahwa bagi hasil, tingkat suku bunga, promosi, inflasi, pengaruh liquiditas (FDR), dan jumlah kantor secara bersama-sama berpengaruh terhadap deposito mudharabah .

Pengujian terhadap variabel $\mathrm{X}_{1}$ (Bagi hasil), nilai t tabel uji dua sisi maka diperoleh nilai sebesar 1.684.Sedangkan untuk nilai $\mathrm{t}$ hitung sebesar2.846698. Berdasarkan hasil diatas maka dapat diketahui bahwa $\mathrm{t}$ hitung $>\mathrm{t}$ tabel, sehingga $\mathrm{H}_{\mathrm{o}}$ ditolak dan $\mathrm{H}_{\mathrm{a}}$ diterima. Hal ini menunjukan bahwa bagi hasil berpengaruh signifikan terhadap deposito mudharabah.

Pengujian terhadap variabel $\mathrm{X}_{2}$ (tingkat suku bunga), nilai $\mathrm{t}$ tabel uji dua sisi maka diperoleh nilai sebesar 1.684.Sedangkan untuk nilai t hitung sebesar 0.966568.Berdasarkan hasil diatas maka dapat diketahui bahwa $t$ hitung $<\mathrm{t}$ tabel, sehingga $\mathrm{H}_{\mathrm{o}}$ diterima dan $\mathrm{H}_{\mathrm{a}}$ ditolak. Hal ini menunjukan bahwa tingkat suku bunga tidak berpengaruh terhadap deposito mudharabah.

Pengujian terhadap variabel $\mathrm{X}_{3}$ (Promosi), nilai $\mathrm{t}$ tabel uji dua sisi maka diperoleh nilai sebesar 1.684. Sedangkan untuk nilai t hitung sebesar 1.744646. Berdasarkan hasil diatas maka dapat diketahui bahwa $t$ hitung $>\mathrm{t}$ tabel, sehingga $\mathrm{H}_{\mathrm{o}}$ ditolak dan $\mathrm{H}_{\mathrm{a}}$ diterima.Hal ini berarti promosi berpengaruh signifikan terhadap deposito mudharabah.

Pengujian terhadap variabel $\mathrm{X}_{4}$ (Inflasi), nilai t tabel uji dua sisi maka diperoleh nilai sebesar 1.684.Sedangkan untuk nilai $t$ hitung sebesar -1.170763.Berdasarkan hasil diatas maka dapat diketahui bahwa $t$ hitung $<\mathrm{t}$ tabel, sehingga $\mathrm{H}_{\mathrm{o}}$ diterima dan $\mathrm{H}_{\mathrm{a}}$ ditolak. Hal ini berarti inflasi tidak berpengaruh terhadap deposito mudharabah.

Pengujian terhadap variabel $\mathrm{X}_{5}(\mathrm{FDR})$, nilai $\mathrm{t}$ tabel uji dua sisi maka diperoleh nilai sebesar 1.684.Sedangkan untuk nilai $t$ hitung sebesar-1.626247. Berdasarkan hasil diatas maka dapat diketahui bahwa $t$ hitung $>\mathrm{t}$ tabel, sehingga $\mathrm{H}_{\mathrm{o}}$ diterima dan $\mathrm{H}_{\mathrm{a}}$ ditolak. Hal ini berarti FDR tidak berpengaruh terhadap deposito mudharabah.

Pengujian terhadap variabel $\mathrm{X}_{6}$ (Jumlah kantor), nilai $\mathrm{t}$ tabel uji dua sisi maka diperoleh nilai sebesar 1.684. Sedangkan untuk nilai $t$ hitung sebesar 10.56086. Berdasarkan hasil diatas maka dapat diketahui bahwa $t$ hitung $>\mathrm{t}$ tabel, sehingga $\mathrm{H}_{\mathrm{o}}$ ditolak dan $\mathrm{H}_{\mathrm{a}}$ diterima. Hal ini berarti jumlah kantor berpengaruh terhadap deposito mudharabah.

\section{Hasil dan Pembahasan}

\section{Pengaruh Tingkat Bagi Hasil Terhadap Deposito Mudharabah}

Dari hasil estimasi variabel tingkat bagi hasil menunjukkan nilai koefisien sebesar 0.644145 dan probabilitas sebesar 0.0065 yang artinya memiliki hubungan positif dan berpengaruh signifikan terhadap deposito mudharabah. Dilihat dari nilai koefisien varibel bagi hasil dapat diartikan ketika tingkat bagi hasil meningkat sebesar $1 \%$ maka deposito mudharabah akan meningkat 0.6441 rupiah.

Berdasarkan uji hipotesis, nilai tingkat bagi hasil berpengaruh terhadap deposito mudharabah. Tidak dapat dipungkiri bahwa dalam setiap investasi hal pertama yang menjadi pertimbangan adalah tingkat keuntungan yang akan diperoleh. Begitu pada investasi mudharabah, nasabah akan memperhitungkan berapa keuntungan yang akan diperoeh oleh nasabah. Karena imbal hasil tidak dapat diketahui paling tidak nasabah dapat menentukan tingkat imbal hasil yang diharpakan harus sesuai dengan ekspektasi nasabah. Tingkat ambil hasil inilah yang sangat menetukan daya saing deposito mudharabah dibandingkan dengan deposito konvensional.

Umunya, saat bagi hasil deposito mudharabah mengalami kenaikan secara signifikan akan mempengaruhi nasabah untuk menambah dananya pada deposito. Begitu pula sebaliknya ketika bagi hasil deposito mengalami penurunan maka nasabah akan melakukan dua pilihan yaitu tetap mendepositokan dananya pada perbankan syariah atau berhenti untuk menggunakan jasa perbankan syariah dan/atau berganti pada jasa perbankan konvensioanal. Perubahan pegambilan keputusan nasabah inilah yang akan mempengaruhi jumlah deposito mudharabah.

Penelitian ini sesuai dengan penelitian yang dilakukan oleh Rachmawati dan Syamsulhakim (2004), Nelwani (2013) dan Anisah (2013) dimana peningkatan tingkat bagi hasil deposito mudharabah akan diikuti dengan peningkatan jumlah deposito mudharabahnya. Akan tetapi, hasil penelitian ini berbeda dengan penelitian Wulansari (2015) dimana tingkat bagi hasil deposito mudharabah berpengaruh negatif signifikan terhadap jumlah deposito di bank syariah. Kedua perbedaan ini dapat dipahami bagi hasil bank syariah yang sudah mengalami kenaikan dari tahun ke tahun, masih belum dapat lebih tinggi dibandingkan dengan tingkat pengembalian pada bank konvensional atau instrumen investasi lain. Sehingga meskipun peningkatan bagi hasil deposito mudharabah sudah tinggi tidak mampu memberikan dampak signifikan pada terhadap jumlah deposito mudharabah.

Akan tetapi, melihat banyaknya penelitian yang menunjukkan bahwa tingkat bagi hasil yang ditawarkan oleh bank syariah sangat berpengaruh terhadap jumlah deposito bank syariah, maka akselerasi skema bagi hasil perlu ditingkatkan. Hal ini mengindikasikan bahwa bank syariah dapat mengambil ceruk pasar penghimpunan 
dana yang dengan memberikan penawaran imbal hasil yang kompetitif sehingga lebih banyak masyarakat yang menginvestasikan dananya dalam bentuk deposito mudharabah.

Semakin meningkatnya deposito di bank syariah, secara tidak langsung akan menambah kepercayaan masyarakat dalam menggunakan produk bank syariah lainnya. Skema bagi hasil yang tidak terdapat dalam perbankan konvensional merupakan sebuah keunggulan tersendiri dibandingkan dengan sistem bunga.

\section{Pengaruh Biaya Promosi Terhadap Deposito Mudharabah}

Dari hasil estimasi variabel biaya promosi menunjukkan nilai koefisien sebesar 0.01404 dan probabilitas sebesar 0.0876 yang artinya memiliki hubungan positif dan berpengaruh signifikan terhadap deposito mudharabah. Dilihat dari nilai koefisien varibel biaya promosi dapat diartikan ketika biaya promosi meningkat sebesar 1 rupiah maka deposito mudharabah angkat meningkat sebesar 0.0140 rupiah.

Berdasarkan uji hipotesis, biaya promosi berpengaruh positif terhadap deposito mudharabah Penelitian ini sesuai penelitian yang dilakukan oleh Mutaqiena (2013) dan Nelwani (2013) dimana biaya promosi akan meningkatakan jumlah deposito pada bank syariah. Promosi merupakan kegiatan yang sangat penting untuk menarik nasabah. Dalam kegiatan ini setiap bank berusaha untuk mempromosikan seluruh produk dan jasa yang dimilikinya baik langsung maupun tidak langsung.

Bentuk promosi saat ini dapat lebih meluas dan tidak terbatas pada cara tradisional menggunakan brosur atau media cetak lainnya. Pemanfaatan teknologi untuk promosi lebih efektif disampaiakn kepada nasabah daripada metode tradisional. Masuknya era digital menuntut perbankan syariah untuk mengikuti perkembangan teknologi yang sudah masuk diseluruh lapisan kehidupan masyarakat. Meskipun keaikan biaya promosi secara statistik siginifikan dengan peningkatan jumlah deposito mudharabah, namum loyalitas nasabah juga harus menajdi perhatian. Bisa jadi nasabah hanya menginginkan iklan yang ditawarkan. Sehingga apabila tidak sesuai dengan yang diharpkan makan dengan mudah akan menaik kembali dananya. Tentu hal ini akan merugikan bank syariah. Selain itu, biaya promosi yang tidak sedikit juga harus menjadi perhatian khusus Biaya yang harus ditanggung memang harus menjadi perhatian

\section{Pengaruh Jumlah Kantor Terhadap Deospito Mudharabah}

Dari hasil estimasi variabel jumlah kantor menunjukkan nilai koefisien sebesar 93.0141 dan probabilitas sebesar 0.0000 yang artinya jumlah kantor memiliki hubungan positif dan signifikan terhadap deposito mudharabah. Dilihat dari nilai koefisien varibel bagi hasil dapat diartikan ketika jumlah kantor meningkat sebesar 1 unit maka deposito mudharabah akan meningkat sebesar 93.0141 rupiah.

Berdasarkan uji hipotesis, jumlah kantor berpengaruh signifikan terhadap deposito mudharabah. Jumlah kantor juga menjadi pertimbangan sendiri bagi masyarakat yang ingin menyimpan dananya pada bank syariah. Banyaknya kantor yang tersebar luas akan mempermudah masyarakat dalam memenuhi transaksi perbankan. Tidak dapat dipungkiri, semakin banyak kantor cabang yang dimiliki perbankan mampu semakin dapat menjangkau lokasi nasabah. Mengingat letak geografis Indonesia yang masih sangat memerlukan kantorkantor cabang di beberapa wilayah yang kurang terjangkau. Kendala penambahan jumlah kantor pada bank syariah menjadi permasalahan tersendiri yang dihadapi oleh perbankan syariah. Biaya pendirian kantor cabang baru yang tidak sedikit menjadi salah satu penghambatnya.

\section{Pengaruh Tingkat Suku Bunga, Inflasi dan FDR}

Hasil estimasi dari variabel tingkat suku bunga, inflasi dan FDR menunjukkan hasil yang tidak signifikan. Hasil estimasi variabel tingkat suku bunga menunjukkan nilai koefisien sebesar 2.0307 dan probabilitas sebesar 0.3458. Nilai ini menunjukkan tingkat suku bunga memiliki hubungan positif tetapi tidak signifikan terhadap deposito mudharabah. Penelitian ini sesuai dengan penelitian yang dilakukan oleh Al Arif \& Hanifah (2017) bahwa tingkat bunga tidak akan mempengaruhi besarnya jumlah deposito mudharabah. Akan tetapi penelitian yang dilakukan oleh Nelwani (2013) dan Kasri dan Kassim (2009) menemukan hal yang sebaliknya. Dimana tingkat suku bunga akan mempengaruhi jumlah deposito mudharabah.

Tingginya kesadaran masyarakat terhadap aspek religiusitas dalam bertransaksi semakin meningkat. Sebagaimana penelitian yang dilakukan oleh Kasri dan Kassim (2009) bahwa aspek religiusitas dapat menjadi salah satu penyebab tingkat penghimpunan deposito mudharabah di perbankan syariah.

Dari hasil pengujian yang telah dilakukan ditemukan hasil yang konsisten terhadap faktor yang dapat mempengaruhi deposito mudharabah. Tingginya return yang ditawarkan akan menarik nasabah untuk menyimpan dananya menggunakan skema deposito mudharabah. Hasil pengujian yang sama juga terjadi pada pengaruh variabel inflasi. Tingkat inflasi yang terjadi di Indonesia tidak mempengaruhi tingkat deposito mudharabah bank syariah. selanjutnya tingginya usaha bank syariah dalam peningkatan layanan kepada nasabah 
juga bmemberikan dampak positif untuk peningkatan produk pendanaan bank syariah khususnya pada deposito mudharabah.

\section{Kesimpulan}

Penelitian ini mempunyai implikasi terhadap bank syariah, yang menunjukan bahwa tingkat bagi hasil, biaya promosi, dan jumlah kantor memiliki pengaruh terhadap penghimpun dana pihak ketiga (deposito mudharabah). Jumlah bagi hasil yang berpengaruh positif menunjukkan bahwa jumlah bagi hasil masih menjadi salah satu motivasi nasabah setelah pendapatan, dalam menginvestasikan dananya pada produk deposito mudharabah. Jika jumlah bagi hasil atau profitabilitas bank syariah semakin tinggi, maka nasabah akan se makin tertarik untuk menginvestasikan da nanya pada produk deposito mudharabah. Promosi harus lebih ditingkatkan lagi, karena dengan promosi masyarakat akan lebih mengenal dan mengerti tentang deposito mudharabah, dan disarankan untuk lebih memperluas jaringan kantor di setiap daerah agar memudahkan masyarakat dalam menjangkaunya.

\section{Daftar Pustaka}

Ascarya. (2007). Akad dan Produk Bank Syariah. Jakarta: PT. Raja Grafindo Persada

Anisah, N. (2013). Faktor-faktor yang mempengaruhi pertumbuhan Deposito Mudharabah Bank Syariah. Jurnal Ilmu dan Riset Akuntansi, 1 (2).

Boediono. (1992). Ekonomi Moneter Edisi III, BPFE: Yogyakarta.

DSN-BI, (2000). Himpunan Fatwa Dewan Syariah Nasional untuk Lembaga Keuangan Syariah. Dewan Syariah Nasional-Bank Indonesia: Jakarta.

Ismail. (2010). Perbankan Syariah. Kencana Pernada Media Group, Jakarta

Iswardono. (1979). Uang dan Bank Edisi VI, BPFE: Yogyakarta.

Karim, A. (2004). Bank Islam (Analisis Fiqih dan Keuangan) Edisi kedua. Jakarta: Raja Grafindo Persada.

Kasri, R. A. \& Kassim, S. (2009). Empirical Determinants of Saving in the Islamic Banks: Evidence from Indonesia. JKAU: Islamic Econ., 22 (2), 181-201

Muhammad. (2011). Manajemen Bank Syariah, STIE YKPN: Yogyakarta.

Mutaqqiena, A. (2013). Analisis Penagruh PDB, Inflasi, Tingkat Bunga, dan Nilai Tukar Terhadap Dana Pihak Ketiga Perbankan Syariah di Indonesia 2008-2012. Economics Development Analysis Journal, 2 (3)

Nelwani, C. Y. E. (2013). Faktor-faktor yang mempengaruhi Deposito Mudharabah pada Bank Umum Syariah Tahun 2009-2011. Skripsi tidak dipublikasikan, Universitas Islam Negeri Sunan Kalijaga, Yogyakarta.

Rivai, V. \& A. Arifin. (2010). Islamic Banking. Jakarta: Bumi Aksara.

Roziq, A. (2013). Variabel Penentu Dalam Keputusan Memilih Tabungan Mudharabah pada Bank Syariah Mandiri, JEAM XII (1)

Rachmawati, E., \& Syamsulhakim, E. (2004). Factors affecting Mudaraba deposits in Indonesia. In Third International Islamic Banking and Finance Conference.

Rudiansyah, A., \& Wuryani, E. (2014). Pengaruh Inflasi, BI Rate, PDB dan Nilai Tukar Rupiah terhadap Simpanan Mudharabah pada Bank Syariah di Indonesia. Jurnal Ilmu Manajemen (JIM), 2(2).

Wulandari, S., \& Aisjah, S. (2013). Analisis Faktor Internal dan Eksternal yang Mempengaruhi Total Dana Pihak Ketiga (DPK) Bank Umum Syariah di Indonesia (Studi Pada Bank Umum Syariah Periode 2011 2013). Jurnal Ilmiah Mahasiswa FEB, 2(1).

Wulansari, D. I., \& Burhan, M. U. (2016). Pengaruh Bagi Hasil dan Suku Bunga Terhadap Jumlah Deposito Mudharabah (Studi Kasus Perbankan Syariah Tahun 2009-2013). Jurnal Ilmiah Mahasiswa FEB, 3(2).

Al Arif, M., \& Hanifah, H. (2017). Determinan Deposito Pada Bank Umum Syariah: Model Regresi Panel. Jurnal Ekonomi Kuantitatif Terapan,. doi:10.24843/JEKT.2017.v10.i01.p05 